\title{
Tiga dekade laju perubahan garis pantai di Kota Dumai
}

\author{
Aras Mulyadi ${ }^{*}$, Rasoel Hamidy ${ }^{2}$, Musrifin ${ }^{3}$, Efriyeldi $^{4}$, Romie Jhonnerie ${ }^{5}$ \\ 1,2,3,4 Program Doktor Ilmu Lingkungan Pascasarjana dan Jurusan Ilmu Kelautan, Fakultas Perikanan dan \\ Kelautan, Universitas Riau \\ ${ }^{5}$ Jurusan Pemanfaatan Sumberdaya Perikanan, Fakultas Perikanan dan Kelautan, Universitas Riau
}

*Koresponden E-mail: aras.mulyadi@1ecturer.unri.ac.id

(Diterima: 01 September 2021|Disetujui: 30 Desember 2021|Diterbitkan: 31 Januari 2022)

\begin{abstract}
Mapping of coastline changes helps in coastal development and monitoring. The city of Dumai, on the east coast of Riau Province, has undergone significant and radical changes caused by the intervention of humans and nature over the past three decades. This study mapped and measured the rate of change of the coastline of Dumai City for 30 years. The Landsat (TM, and OLI) image series, 1990, 1999, 2008, and 2020 became a data source to generate coastlines through on-screen digitization techniques, then to study the temporal behavior of coastlines using the Digital Shoreline Analysis System (DSAS) and geographic information systems to describe the spatial and temporal variations of coastlines. The results showed that the coastline length during the observation ranged from 123,14 to 125,23 km, while the average accretion rate was 1.17 meters per year while the average abrasion rate was 2.04 meters per year. Those rates of change affected coastline expanded to the sea for 60,82 hectares and eroded 760,20 hectares coastline to the land.
\end{abstract}

Keywords: coastline changes; Dumai; DSAS; GIS; landsat

\section{PENDAHULUAN}

Wilayah pesisir mencakup 2\% dari permukaan planet dan hampir 10\% (600 juta) dari populasi bumi mendiami di wilayah tersebut (Feagin, 2008). Dengan jumlah populasi tersebut telah menyebabkan terjadi dinamika pantai yang disebabkan oleh manusia seperti konstruksi bendungan, drainase, dan penyebab erosi lainnya, tanpa menafikan pengaruh dari alam, seperti gelombang dan arus pasang surut, angin kencang, gempa bumi, erosi. Fenomena tersebut telah mengakibatkan penurunan lingkungan ekologis wilayah pesisir (Sener et al., 2010).

Garis pantai merupakan antarmuka fisik darat dan perairan. Dengan dinamika tinggi melalui interaksi berkelanjutan antara geosfer, hidrosfer, dan atmosfer menyebabkan posisi garis pantai sering berubah seiring waktu berjalan (Boak \& Turner, 2005), karena beberapa parameter morfodinamika seperti pergerakan sedimen (Aquino da Silva et al., 2019) di zona litoral dan sifat dinamis permukaan air di batas pantai (misalnya arus, pasang surut, gelombang) (Leonardi \& Plater, 2017).

Skilodimou et al. (2021) menyarikan pentingnya kajian penentuan garis pantai dan perubahan garis pantai (merupakan fenomena yang bervariasi dalam besaran, kecepatan dan durasi), diperlukan untuk menilai: perubahan muka air laut, perlindungan zona pantai, memperkirakan perkembangan pantai, membantu dalam pemantauan pesisir, evolusi pesisir dan menilai bahaya pesisir. Dalam beberapa dekade terakhir, data observasi bumi seperti foto udara (Nikolakopoulos et al., 2019), citra satelit (Xu \& Gong,
2018), dan data GPS (Garrido et al., 2013) telah menjadi sumber dan sarana integral untuk melakukan evaluasi perubahan garis pantai. Data tersebut tersedia secara temporal pada lokasi yang sama dalam deret waktu yang panjang dan lebih hemat biaya.

Saat ini untuk menghitung tingkat perubahan historis garis pantai dan untuk memprediksi perubahan garis pantai dengan tingkat akurasi yang tinggi dapat dilakukan dengan mudah (Appeaning Addo et al., 2008). United States Geological Survey (USGS) mengembangkan sebuah plug-in sistem informasi geografis sebagai platform bernama Digital Shoreline Analysis System (DSAS) menggunakan pendekatan berbasis observasi. Ini menghasilkan transek adukan semen dan batu kerikil tegak lurus terhadap garis dasar referensi pada jarak yang ditentukan pengguna pada sepanjang garis pantai. Jarak antara garis dasar dan setiap titik perpotongan garis pantai pada transek membantu dalam menghitung perubahan garis pantai baik dengan pengukuran jarak dan perhitungan statistik terkait dan menghasilkan semua perhitungan yang terhubung ke file transek dengan tabel atribut. DSAS membantu menentukan perilaku morfodinamika garis pantai dan pergeseran yang terkait dengan geometri tepi pantainya (Moussaid et al., 2015). Pemantauan perubahan garis pantai adalah cara yang efektif untuk mempelajari perubahan lingkungan dan ekologi zona pantai. Oleh karena itu, pemantauan garis pantai telah menjadi tugas penting untuk pembangunan berkelanjutan dan perlindungan lingkungan.

Dalam penelitian ini telah dilakukan upaya untuk mengidentifikasi dan menghitung laju 
perubahan garis pantai Kota Dumai dari tahun 1990 hingga 2020. Seri citra Landsat telah digunakan untuk mengukur laju perubahan garis pantai akibat campur tangan manusia maupun alami. Metode ini efisien, cepat, andal, dan ekonomis. Singkatnya, ini adalah alat yang berguna untuk merekam dan memantau perubahan garis pantai.

\section{BAHAN DAN METODE}

\section{Lokasi penelitian}

Penelitian dilakukan sepanjang garis pantai $(121,12 \mathrm{~km})$ Kota Dumai (Gambar 1). Memiliki

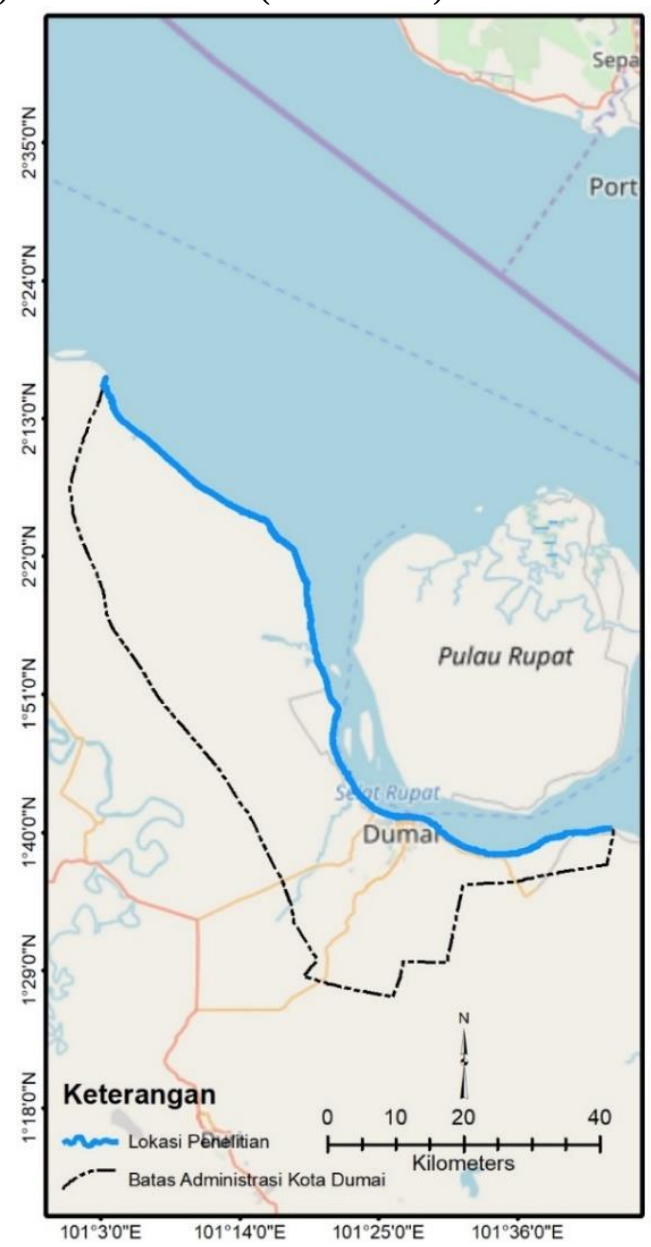

wilayah daratan seluas 204.674 hektar dan perairan seluas 71.393 hektar, terletak pada posisi antara

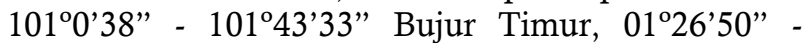
$02^{\circ} 15^{\prime} 40^{\prime \prime}$ Lintang Utara. Berdasarkan topografi wilayah Kota Dumai merupakan dataran rendah dengan ketinggian $1,3-2,5 \mathrm{~m}$ dpl dan dengan kemiringan antara 0-1 \%. Dari data Litbang Sumberdaya Lahan Pertanian tahun 2011, 72\% tanah di dataran Kota Dumai merupakan tanah gambut dan sebagian besar memiliki kedalaman $>300 \mathrm{~cm}(46,3 \%$ dari total luas gambut kota Dumai).

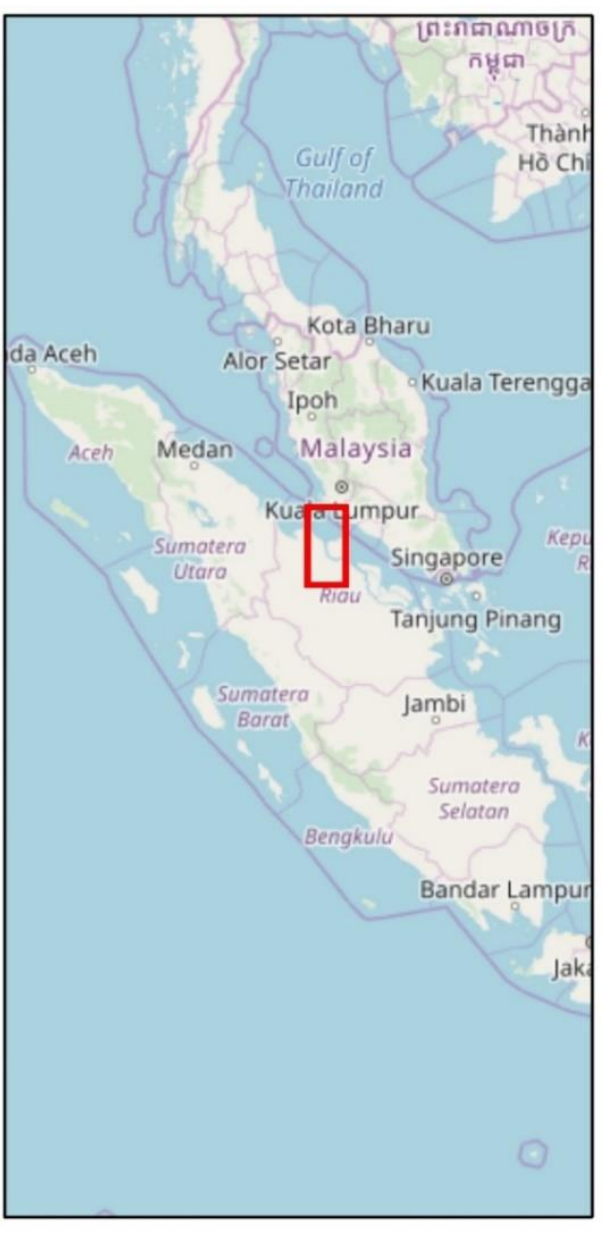

Gambar 1. Lokasi penelitian sepanjang garis pantai Kota Dumai

Salah satu isu strategis pembangunan Kota Dumai adalah perkembangan permukiman lama yang awalnya merupakan kawasan permukiman nelayan tepian yang berkembang di sepanjang garis pantai. Seiring perjalanan waktu Kota Dumai telah berkembang dan berubah menjadi kawasan industri yang menguasai sebagian besar wilayah pantai. Perubahan wajah Kota Dumai yang disebabkan oleh faktor industrialisasi mendorong terjadinya proses urbanisasi yang menyebabkan terjadi pergeseran perkembangan permukiman di kota dari yang awalnya merupakan permukiman kota nelayan menjadi permukiman kota industri (Direktorat Jendral Cipta Karya, 2017).

\section{Data}

Data yang digunakan terdiri dari: i) 4 seri citra satelit Landsat TM dan OLI, level 2A, path/row 127/59 yang diakusisi pada tanggal 15 September 1990, 21 Juli 1999, 4 Desember 2008 dan 18 Nopember 2020, diunduh melalui portal EarthExplorer (http://earthexplorer.usgs.gov). Citra Landsat telah banyak digunakan dalam ekstraksi garis pantai dan penelitian di wilayah pesisir karena memiliki seri data yang panjang, resolusi tinggi dan ketersediaan bebas sejak munculnya teknologi penginderaan jauh satelit pada tahun 1970-an (Athanasiou et al., 2019; Luijendijk et al., 2018). Citra yang digunakan telah dikoreksi terrain, koreksi tersebut menggunakan titik 
kontrol tanah dan model elevasi digital untuk mencapai akurasi geodetik tinggi dan nilai digital yang dimilikinya adalah nilai pantulan objek permukaan (Level 2). Boak and Turner (2005) merekomendasikan citra satelit sebagai salah satu sumber data untuk pendeteksian garis pantai. ii) Peta digital batas administrasi Kota Dumai dalam format shapefile (.shp), diperoleh melalui laman Geospasial untuk Negeri (https://tanahair.indonesia.go.id). iii). Meskipun penggunaan citra satelit Landsat sudah jamak digunakan untuk khususnya dalam kajian garis pantai (Choung \& Jo, 2016). Namun banyak kemiripan objek garis pantai yang dijumpai pada citra tersebut, seperti tanggul garam dan akuakultur serta garis pantai berpasir dan berlumpur. Karena kerumitan tersebut diperlukan bantuan dari citra reolusi tinggi yang disediakan oleh layanan daring Web Map Tile Service (WMTS) dari Google MapImagery, Bing MapImagery dan layanan citra satelit melalui Google Earth Pro. untuk meningkatkan akurasi lokasi dan jenis objek pantai lainnya(Yu et al., 2018).

\section{Deliniasi garis pantai}

Beberapa metode standar delineasi garis pantai saat ini telah berkembang, untuk memfasilitasi pemantauan perubahan garis pantai menggunakan pengindraan jauh. Garis pantai dalam kajian ini adalah garis air pada saat perekaman citra satelit (Sui et al., 2020). Esmail et al. (2019) melakukan perbandingan tiga metode ekstraksi garis pantai, yaitu squared error clustering method (SECM), penggunaan nilai ambang batas dan digitasi, dan menyimpulkan metode SECM adalah metode terbaik, tetapi metode tradisional melalui interpretasi visual manusia dan interaksi komputer masih umum digunakan para ahli untuk mendeliniasi garis pantai (Zhou et al., 2019). Oleh karena itu kajian ini mengadopsi metode tersebut. Data citra satelit Landsat disajikan melalui komposit warna semu (RGB) 543 dibantu dengan penajaman melalui perajangan nilai digital, sehingag secara visual dapat dipisahkan objek daratan dan perairan dan dilanjutkan pendigitasian batas air dan daratan.
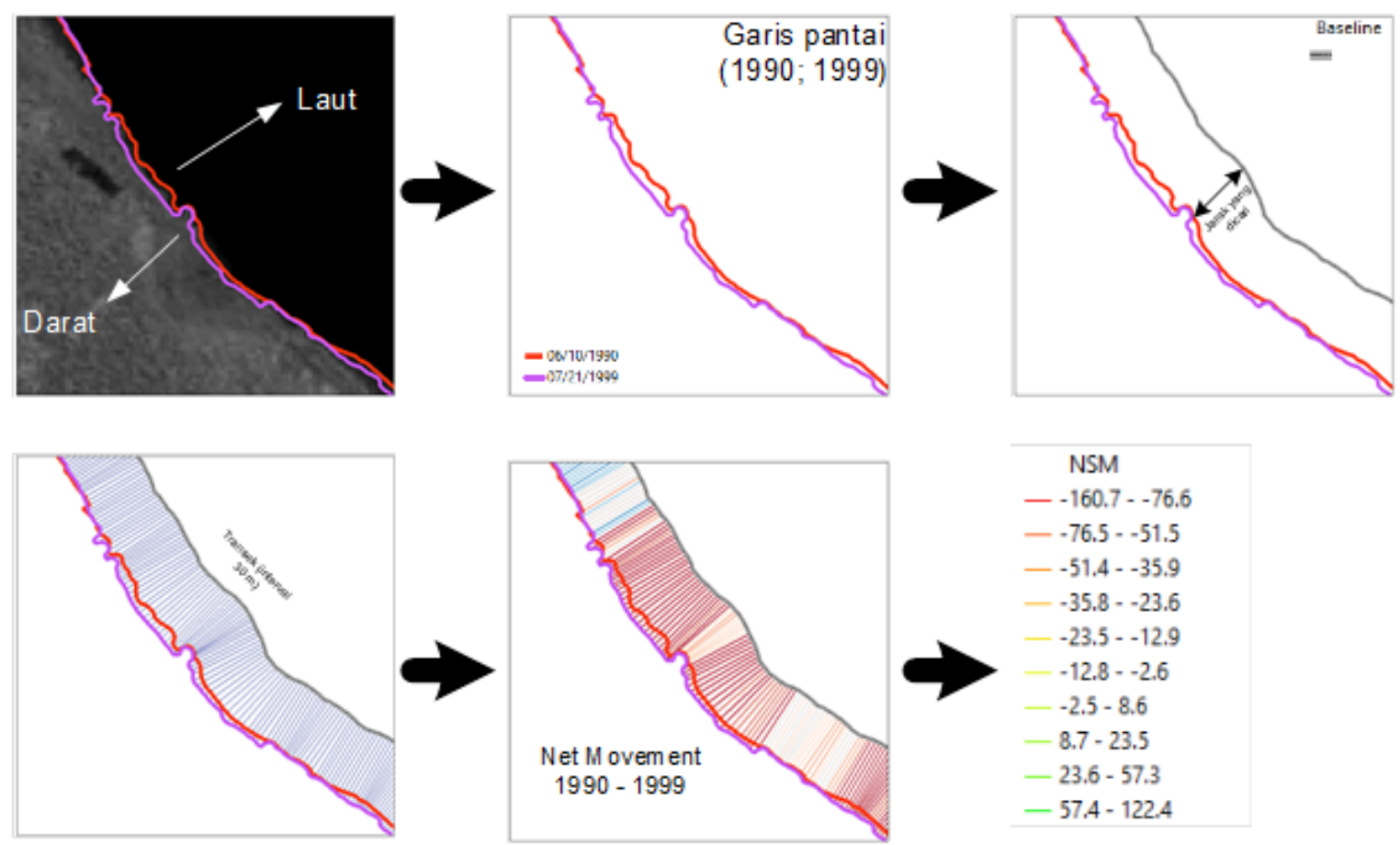

Gambar 2. DSAS digunakan untuk menentukan pergerakan antara garis pantai, 1990 - 1999

\section{Estimasi laju perubahan garis pantai}

Digital Shoreline Analysis System (DSAS) digunakan untuk menghitung laju perubahan garis pantai (shoreline change envelope dan Net Shoreline Movement) dan beberapa hitungan statistik (End Point Rate, Linear Regression Rate dan Weighted Linerar Regression Rate). Penelitian ini menggunakan plug-in DSAS pada ArcGIS Environmental System Research Institute (ESRI) (Thieler et al., 2017). Pengoperasian DSAS, diawali dengan penentuan suatu garis pangkal (baseline) di sepanjang garis pantai sedemikian rupa sehingga garis pangkal tersebut tegak lurus terhadap garis pantai dan merupakan referensi garis pantai dan menjadi dasar dalam perhitungan pergerakan garis pantai. Selanjutnya melalui cast transect DSAS memotong setiap garis pantai untuk membuat titik pengukuran, dan titik pengukuran ini menghitung laju perubahan garis pantai.

DSAS diterapkan pada garis pantai Kota Dumai yang diekstraksi dan diilustrasikan melalui Gambar 2. Transek yang ditunjukkan pada Gambar 2, mewakili pergerakan garis tepi pantai antara dua tahun melalui warna garis yang dikategorikan ke dalam rentang yang berbeda. Semua transek berubah menjadi warna yang berbeda sesuai dengan jangkauan atau jarak linier yang berubah posisi dari garis tepi (baseline) 
pada lokasi tersebut. Setiap transek mewakili nilai pergerakan total garis pantai dari lokasi di mana transek berada. Nilai positif menunjukkan akresi yaitu, pergerakan tepi daratan ke arah laut. Di sisi lain, nilai negatif menunjukkan abrasi yang merupakan pergerakan ke arah darat dari garis pantai. Jarak maksimum antara baseline dan garis pantai ditetapkan $500 \mathrm{~m}$ dan jarak antara setiap transek ditetapkan $30 \mathrm{~m}$, sesuai dengan ukuran piksel citra Landsat, sebagai sumber derivasi garis pantai. Laju perubahan garis pantai dihitung menggunakan Net Shoreline Movement (NSM). Pergerakan garis pantai bersih memperkirakan jarak antara garis pantai pertama dan terakhir. Laju pergerakan garis pantai dianalisis secara grafis.

Laju pergerakan garis pantai juga dihitung berdasarkan luas (hektar). Garis pantai yang dihasilkan kemudian digabung (merge) dengan batas administrasi Kota Dumai (fitur spasial berupa garis), hasil penggabungan tersebut kemudian diubah menjadi fitur polygon, lalu ditambahkan atribut penanda masing-masing polygon (tahun perekaman sumber data garis pantai), kemudian di-overlay melalui tool geoprocessing union. Seluruh atribut penanda kemudian digabungkan berdasarkan urutan tahun garis $(2020,2008,1999$, dan 1990) menggunakan fungsi ampersand. Jika angka terakhir pada baris penggabungan tersebut menunjukkan angka 2020, maka mengindikasikan terjadinya akresi sementara jika menunjukkan angka 0, maka mengindikasikan abrasi. Dilanjutkan dengan perhitungan luas kejadian abrasi dan akresi.

\section{HASIL DAN PEMBAHASAN}

Panjang garis pantai Kota Dumai berkisar antara 123,14-125,23 km (Tabel 1), dengan selisih panjang maksimal antar garis pantai sebesar $2,08 \mathrm{~km}$, sementara beda panjang dengan garis pantai yang digunakan pada rencana tata ruang wilayah Provinsi Riau (tahun 2016) kurang dari 4 km (maksimal).

Tabel 1. Panjang garis pantai (PGP), selisih panjang antar garis pantai (SGP) dan selisih panjang garis pantai yang berasal dari citra satelit Landsat dengan garis pantai RTRW (SGR).

\begin{tabular}{|c|c|c|c|c|}
\hline $\begin{array}{l}\text { Tahu } \\
\mathrm{n}\end{array}$ & $\begin{array}{l}\text { PGP } \\
(\mathrm{Km})\end{array}$ & $\begin{array}{l}\text { SGP } \\
(\mathrm{Km})\end{array}$ & $\begin{array}{l}\text { SGR } \\
(\mathrm{Km})\end{array}$ & Sumber \\
\hline 1990 & 123,14 & - & 1,93 & $\begin{array}{l}\text { Citra satelit } \\
\text { Landsat } 5 \text { TM }\end{array}$ \\
\hline 1999 & 125,23 & 2,08 & 4,01 & $\begin{array}{l}\text { Citra satelit } \\
\text { Landsat } 5 \mathrm{TM}\end{array}$ \\
\hline 2008 & 123,48 & $-1,74$ & 2,27 & $\begin{array}{l}\text { Citra satelit } \\
\text { Landsat } 5 \mathrm{TM}\end{array}$ \\
\hline 2020 & 124,66 & 1,18 & 3,45 & $\begin{array}{l}\text { Citra satelit } \\
\text { Landsat } 8 \text { OLI }\end{array}$ \\
\hline 2016 & 121,22 & & - & $\begin{array}{l}\text { Batas } \\
\text { administrasi } \\
\text { kabupaten/kot }\end{array}$ \\
\hline & & & & $\begin{array}{l}\text { a, RTRW } \\
\text { Provinsi Riau }\end{array}$ \\
\hline
\end{tabular}

Laju perubahan garis pantai Kota Dumai untuk setiap durasi tahun pengamatan cukup dinamis. Proses akresi dan abrasi terjadi setiap sepanjang tahun, namun proses abrasi lebih mendominasi dinamika pantai. Akresi terpanjang dijumpai pada rentang tahun 1999-2008, sepanjang 267,69 meter dan diperkirakan laju akresi sebesar 2,23 meter per tahun, sementara panjang maksimum berkurangnya garis pantai (abrasi) dijumpai pada tahun 2008-2020 sebesar 232,28 meter dengan laju abrasi sebesar 3,45 meter per tahun. Jika durasi pengamatan diperpanjang maka, laju akresi menurun hingga mencapai angka 1,17 meter per tahun sementara laju abrasi menurun menjadi 2,04 meter per tahun (Tabel 2). Jika dibandingkan dengan perubahan garis pantai di Pulau Rangsang, Kabupaten Meranti, laju abrasi Kota Dumai lebih rendah. Laju abrasi di Pulau Rangsang dalam rentang tahun 1999-2014, berkisar antara $2,80-12,28$ meter per tahun, sementara laju akresi berkisar antara 0,20-8,21 meter per tahun (Hakim et al., 2014). Sementara laju abrasi di Pulau Bengkalis dalam medio 1988-2014 menunjukkan laju abrasi yang lebih tinggi lagi yaitu 32,75 meter per tahun (Sutikno et al., 2017). Tingkat abrasi yang tinggi pada ke dua pulau disebabkan karena sebagian wilayah pesisirnya berhadap langsung dengan perairan Selat Malaka, sehingga tidak terdapat pelindung dari pengaruh dinamika oseanografi yang dapat mempengaruhi garis pantai. Sementara sebagian garis pantai Kota Dumai, tidak langsung berhadapan dengan Selat Malaka, karena dihalangi oleh daratan Pulau Rupat dan beberapa pulau kecil yang memiliki dinamika tersendiri di perairan Selat Rupat.

Tabel 2. Laju akresi dan abrasi (meter) Kota Dumai, berdasarkan seri waktu perekaman data

\begin{tabular}{llll}
\hline Durasi & \multicolumn{2}{l}{ Akresi (meter) } & Pertahun \\
\cline { 2 - 3 } & Maksimum & Rata-rata & \\
$1990-1999$ & 122,38 & $15,28( \pm 18,39)$ & 1,53 \\
$1999-2008$ & 267,69 & $22,30( \pm 26,43)$ & 2,23 \\
$2008-2020$ & 194,82 & $21,54( \pm 28,87)$ & 1,66 \\
$1990-2020$ & 292,42 & $36,15( \pm 49,01)$ & 1,17 \\
Durasi & Abrasi (meter) & Pertahun \\
& Maksimum & Rata-rata & \\
$1990-1999$ & 160,70 & $23,24( \pm 19,30)$ & 2,32 \\
$1999-2008$ & 145,25 & $20,65( \pm 16,77)$ & 2,07 \\
$2008-2020$ & 232,28 & $44,85( \pm 27,12)$ & 3,45 \\
$1990-2020$ & 272,38 & $63,16( \pm 42,96)$ & 2,04 \\
\hline
\end{tabular}

Dinamika perubahan garis pantai pada rentang tahun 1990-1999, terlihat sangat dinamis. Abrasi telah terjadi hampir disepanjang garis pantai Kota Dumai. Semakin mendekati ujung garis pantai Kecamatan Sungai Sembilan, ukuran panjang abrasi semakin panjang, lebih dari 100 meter di beberapa lokasi. Sementara akresi lebih banyak dijumpai pada Kecamatan Dumai Timur dan di bagian awal garis pantai Kecamatan Sungai Sembilan. Pada periode 1999-2008, dijumpai fenomena yang terbalik jika dibandingkan periode 1990-1999. Akresi terpanjang (> 200 meter) terjadi di ujung Kecamatan Medang 
Kampai dan Dumai Timur. Pada pengamatan periode akhir, 2008-2020, terlihat kejadian abrasi sangat mendominasi di sepanjang garis Pantai Kota Dumai, dan akresi juga dapat dijumpai di beberapa bagian garis pantai setiap kecamatan. Pengamatan selama 31 tahun (1990-2020) memiliki pola yang hampir sama dengan kejadian pada periode 2008-2020 (Gambar 3).

Perubahan garis pantai dipicu akibat perubahan penutup lahan secara signifikan dari hutan rawa gambut menjadi perkebunan kelapa sawit yang mengakibatkan neraca air tidak terdistribusi dengan baik berdasarkan ruang dan waktu. Hal ini diperparah lagi oleh banyaknya perkebunan yang membuat daerah ini mudah kering. Hal ini membuat muka air tanah semakin rendah dan material gambut di permukaan menjadi kering terutama pada musim kemarau. Saat musim hujan tiba, curah hujan akan meningkatkan massa tanah gambut melalui peningkatan kadar air. Hal ini akan mengurangi kestabilan lereng gambut yang akan menyebabkan kegagalan gambut (Sutikno et al., 2017). Namun pengaruh ekspansi perkebunan sawit di Provinsi Riau, memberikan kontribusi perubahan garis pantai yang berbeda dengan pendapat Skilodimou et al. (2021), bahwa ekspansi tersebut berkontribusi terhadap perluasan daratan sebesar 1777,73 $\mathrm{km} 2$ atau sebesar $23,08 \%$ dari pertambahan daratan nasional. Pertentangan ini menjadi menarik untuk dikaji lebih mendalam, mengingat isu perubahan garis pantai di Provinsi Riau lebih didominasi pengurangan garis pantai dari pada penambahan daratan. Sementara penelitian ini menghitung telah terjadi pengurangan luas daratan Kota Dumai sebesar 760,20 hektar dan penambahan daratan hanya sebesar 60 hektar (Tabel 3). Pendapat senada juga disampaikan oleh Hakim et al. (2014) dan (Hakim et al., 2014); Sutikno et al. (2017) dalam menghitung perubahan garis pantai di Pulau Bengkalis dan Pulau Meranti, Provinsi Riau.

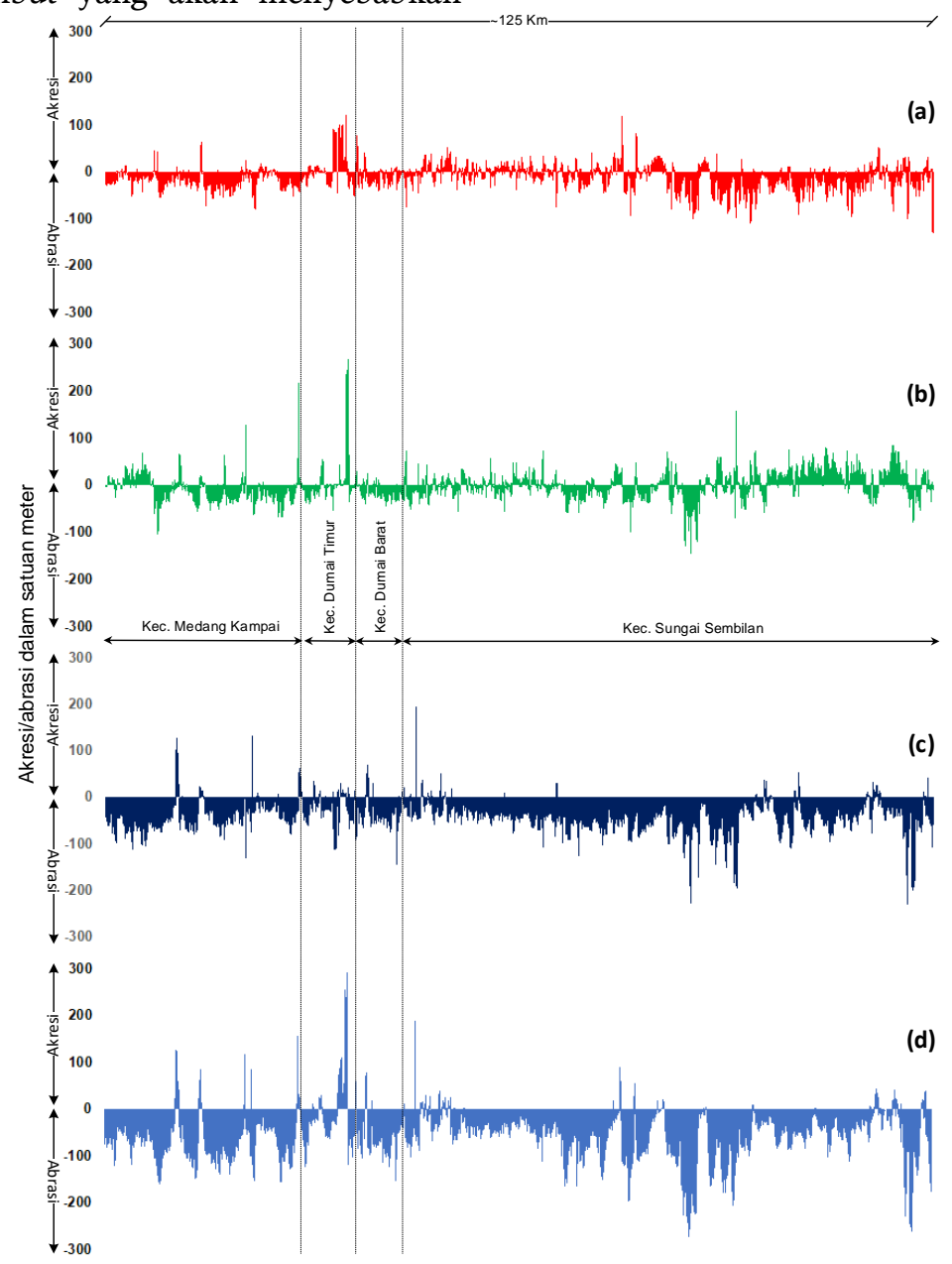

Gambar 3. Grafik transek tegak lurus antar garis pantai yang mencerminkan dinamika perubahan garis pantai. Nilai positif pada setiap sumbu vertikal mengindikasikan panjang penambahan daratan (akresi), sementara nilai negatif mengindikasikan panjang pengurangan daratan (abrasi). Perubahan dinyatakan dalam satuan meter. Pengamatan dinamika garis pantai (a) 1990-1999 (b) 1998-2008. (c) 2008-2020. (d) 1990-2020. 
Tabel 3. Laju abrasi dan akresi Kota Dumai berdasarkan luas (hektar), tahun 1990-2020

\begin{tabular}{llll}
\hline Kecamatan & $\begin{array}{l}\text { Luas } \\
\text { (ha) }\end{array}$ & Abrasi & $\begin{array}{l}\text { Luas } \\
\text { Akresi(ha) }\end{array}$ \\
\hline Medang & 200,29 & 12,23 \\
Kampai & & 19,22 \\
Dumai Timur & 24,83 & 3,56 \\
Dumai Barat & 44,87 & 25,80 \\
Sungai & 490,22 & 60,82 \\
Sembilan & & \\
Jumlah & 760,20 & \\
\hline
\end{tabular}

Penyebab perubahan garis pantai lainnya adalah dinamika oseanografi di perairan Selat Rupat, berupa: i) naik turunnya muka air laut secara teratur yang mempengaruhi arus di sekitar pantai dan geomorfologi pantai. ii) gelombang laut, ketinggian gelombang berkaitan dengan bahaya penggenangan air laut dan transpor sedimen di sepanjang pantai. Dampak tingginya gelombang yang menghantam pantai akan berpengaruh terhadap perubahan garis pantai yang terjadi di sepanjang pantai. Semakin besar energi gelombang laut yang menghantam maka partikel sedimen yang masuk maupun yang keluar pantai akan semakin besar begitupun sebaliknya. (Handartoputra et al., 2015).

\section{KESIMPULAN}

Studi ini menunjukkan bahwa Digital Shoreline Analysis System (DSAS) berbasis SIG telah berhasil mengekstrak informasi penting laju dinamika garis pantai baik penambahan (akresi) maupun pengurangan (abrasi). Dinamika dari tahun 1990-1999 dan 1999-2008, merupakan masa perubahan yang sangat dinamis, baik untuk penambahan maupun pengurangan garis pantai, sementara pada periode 2008-2020 lebih didominasi pengurangan garis pantai. Laju akresi Kota Dumai 1, 17 meter per tahun sementara laju abrasi sebesar 2,04 meter per tahun. Laju perubahan itu mengakibatkan penambahan daratan seluas 60,82 hektar dan mengurangi daratan sebesar 760,20 hektar.

\section{UCAPAN TERIMAKASIH}

Terima kasih kami sampaikan kepada Pemerintah Kota Dumai yang telah memfasilitasi penelitian sehingga penelitian ini berjalan dengan lancar. Kemudian kami sampaikan bahwa penelitian ini didukung oleh biaya yang bersumber dari DIPA BLU Universitas Riau Tahun 2021 pada skim Penelitian Unggulan Universitas Riau dengan Nomor Kontrak: 511/UN.19.5.1.3/PT.01.3/2021.

\section{DAFTAR PUSTAKA}

Appeaning Addo, K., Walkden, M., \& Mills, J. P. (2008). Detection, measurement and prediction of shoreline recession in Accra, Ghana. ISPRS Journal of Photogrammetry and Remote Sensing, 63(5), 543-558.

https://doi.org/https://doi.org/10.1016/j.isprsjpr s.2008.04.001.

Aquino da Silva, A. G., Stattegger, K., Vital, H., \& Schwarzer, K. (2019). Coastline change and offshore suspended sediment dynamics in a naturally developing delta (Parnaíba Delta, NE Brazil). Marine Geology, 410, 1-15. https://doi.org/https://doi.org/10.1016/j.marge o.2018.12.013.

Athanasiou, P., van Dongeren, A., Giardino, A., Vousdoukas, M., Gaytan-Aguilar, S., \& Ranasinghe, R. (2019). Global distribution of nearshore slopes with implications for coastal retreat. Earth Syst. Sci. Data, 11(4), 1515-1529. https://doi.org/10.5194/essd-11-1515-2019.

Boak, E. H., \& Turner, I. L. (2005). Shoreline Definition and Detection: A Review. Journal of Coastal Research, 2005(214), 688-703, 616. https://doi.org/10.2112/03-0071.1.

Choung, Y.J., \& Jo, M.-H. (2016). Shoreline change assessment for various types of coasts using multitemporal Landsat imagery of the east coast of South Korea. Remote Sensing Letters, 7(1), 91-100. https://doi.org/10.1080/2150704X.2015.1109157

Esmail, M., Mahmod, W. E., \& Fath, H. (2019). Assessment and prediction of shoreline change using multi-temporal satellite images and statistics: Case study of Damietta coast, Egypt. Applied Ocean Research, 82, 274-282.

https://doi.org/https://doi.org/10.1016/j.apor.2 018.11.009.

Feagin, R. A. (2008). Vegetation's Role in Coastal Protection. Science, 320(5873), 176-177. https://doi.org/10.1126/science.320.5873.176b.

Garrido, M. S., Giménez, E., Ramos, M. I., \& Gil, A. J. (2013). A high spatio-temporal methodology for monitoring dunes morphology based on precise GPS-NRTK profiles: Test-case of Dune of Mónsul on the south-east Spanish coastline. Aeolian Research, 8, 75-84.

https://doi.org/https://doi.org/10.1016/j.aeolia. 2012.10.011.

Hakim, A. R., Sutikno, S., \& M., F. (2014). Analisis laju abrasi pantai Pulau Rangsang di Kabupaten Meranti denganmenggunakan data satelit. Jurnal Sains dan Teknologi, 3(2), 57-62.

Handartoputra, A., Purwanti, F., \& Hendrarto, B. (2015). [Kerentanan; CVI; Ekosistem Pantai; Pantai Sendang Biru]. 2015, 7. https://doi.org/10.14710/marj.v4i1.7819. 
Leonardi, N., \& Plater, A. J. (2017). Residual flow patterns and morphological changes along a macroand meso-tidal coastline. Advances in Water Resources, 109, 290-301.

https://doi.org/https://doi.org/10.1016/j.advwat res.2017.09.013.

Luijendijk, A., Hagenaars, G., Ranasinghe, R., Baart, F., Donchyts, G., \& Aarninkhof, S. (2018). The State of the World's Beaches. Scientific Reports, 8(1), 6641. https://doi.org/10.1038/s41598-01824630-6.

Moussaid, J., Fora, A. A., Zourarah, B., Maanan, M., \& Maanan, M. (2015). Using automatic computation to analyze the rate of shoreline change on the Kenitra coast, Morocco. Ocean Engineering, 102, 71-77.

https://doi.org/https://doi.org/10.1016/j.oceane ng.2015.04.044.

Nikolakopoulos, K., Kyriou, A., Koukouvelas, I., Zygouri, V., \& Apostolopoulos, D. (2019). Combination of Aerial, Satellite, and UAV Photogrammetry for Mapping the Diachronic Coastline Evolution: The Case of Lefkada Island. ISPRS International Journal of Geo-Information, $8(11), \quad 489 . \quad$ https://www.mdpi.com/22209964/8/11/489.

Pusat Pengelolaan dan Penyebarluasan Informasi Geospasial Badan Informasi Geospasial (BIG). (2021). Cibinong, INDONESIA. https://tanahair.indonesia.go.id.

Sener, E., Davraz, A., \& Sener, S. (2010). Investigation of Aksehir and Eber Lakes (SW Turkey) Coastline Change with Multitemporal Satellite Images. Water Resources Management, 24(4), 727-745. https://doi.org/10.1007/s11269-009-9467-5.
Skilodimou, H. D., Antoniou, V., Bathrellos, G. D., \& Tsami, E. (2021). Mapping of Coastline Changes in Athens Riviera over the Past 76 Year's Measurements. Water, 13(15), 2135. https://www.mdpi.com/2073-4441/13/15/2135.

Sui, L., Wang, J., Yang, X., \& Wang, Z. (2020). Spatial-Temporal Characteristics of Coastline Changes in Indonesia from 1990 to 2018. Sustainability, 12(8), 3242. https://www.mdpi.com/2071-1050/12/8/3242

Sutikno, S., Sandhyavitri, A., Haidar, M., \& Yamamoto, K. (2017). Shoreline Change Analysis of Peat Soil Beach in Bengkalis Island Based on GIS and RS. International Journal of Engineering and Technology, 9(3), 233-238. https://doi.org/10.7763/IJET.2017.V9.976.

Thieler, E. R., Himmelstoss, E. A., Zichichi, J. L., \& Ergul, A. (2017). Digital Shoreline Analysis System (DSAS) version 4.0-An ArcGIS extension for calculating shoreline change (ver. 4.4, July 2017): U.S. Geological Survey Open-File Report 2008 1278.

$\mathrm{Xu}$, N., \& Gong, P. (2018). Significant coastline changes in China during 1991-2015 tracked by Landsat data. Science Bulletin, 63(14), 883-886. https://doi.org/https://doi.org/10.1016/j.scib.20 18.05.032.

Yu, L., Liu, X., Zhao, Y., Yu, C., \& Gong, P. (2018). Difficult to map regions in $30 \mathrm{~m}$ global land cover mapping determined with a common validation dataset. International Journal of Remote Sensing, 39(12), 4077-4087. https://doi.org/10.1080/01431161.2018.1455238

Zhou, M., Wu, M., Zhang, G., Zhao, L., Hou, X., \& Yang, Y. (2019). Analysis of Coastal Zone Data of Northern Yantai Collected by Remote Sensing from 1990 to 2018. Applied Sciences, 9(20), 4466. https://www.mdpi.com/2076-3417/9/20/4466. 